\title{
Cercopithecine and Colobine Abundance Across Protected and Unprotected Land in the Greater Mahale Ecosystem, Western Tanzania
}

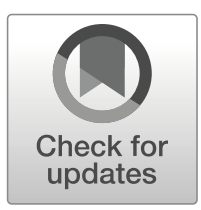

\author{
Edward McLester $^{1}$ (D) Lilian Pintea $^{2} \cdot$ Fiona A. Stewart ${ }^{1,3} \cdot$ Alex K. Piel $^{1,3}$
}

Received: 15 March 2019 / Accepted: 6 November 2019 / Published online: 10 December 2019

(C) The Author(s) 2019

\begin{abstract}
Most primates live in unprotected land where abundances and threats may differ from those in protected areas. We therefore need to establish population densities in both unprotected and protected areas to effectively inform conservation planning. The Greater Mahale Ecosystem in western Tanzania is a region of mixed protected status with seven cercopithecine and colobine species: blue (Cercopithecus mitis doggetti), red-tailed (C. ascanius schmidi), and vervet (Chlorocebus pygerythrus) monkeys; ashy red colobus (Piliocolobus tephrosceles); black-and-white colobus (Colobus angolensis); and olive (Papio anubis) and yellow (P. cynocephalus) baboons. These species may be threatened by increasing human activity; however, except for ashy red colobus, no data on local abundances are available. We walked over $350 \mathrm{~km}$ of line transects in legally protected (Village Forest Reserves) and unprotected general land between August 2011 and October 2012 to estimate densities of primates and human activity. Primate densities were consistently low across the Greater Mahale Ecosystem. Blue and red-tailed monkey and ashy red colobus densities were especially low compared to populations in predominantly forested landscapes. Primate and human activity densities did not differ significantly inside and outside of reserves. Low primate densities could be natural responses to the lower proportions and quality of riparian forest habitat in the region. High levels of human activity and the absence of significantly higher primate densities in reserves suggest unprotected land could provide important refuges for primates in the Greater Mahale Ecosystem. This result further reinforces a broad need to include unprotected areas in primate conservation strategies.
\end{abstract}

Keywords Human disturbance · Mosaic landscape · Primate conservation · Village Forest Reserve

Handling Editor: Joanna M. Setchell

Electronic supplementary material The online version of this article (https://doi.org/10.1007/s10764-01900118-6) contains supplementary material, which is available to authorized users.

Edward McLester

e.mclester@2016.ljmu.ac.uk

Extended author information available on the last page of the article 


\section{Introduction}

Primates are threatened across their range (Estrada et al. 2017), with species loss driven by direct (e.g., hunting and live capture) and indirect (e.g., habitat degradation and disease mortality) threats (Gillespie and Chapman 2008; Plumptre and Johns 2001; Wich and Marshall 2016). Monitoring primate abundance provides information on changes in population size and distribution and is essential for establishing whether a population is vulnerable to extinction (Campbell et al. 2016; Lawton 1993; Pearce and Ferrier 2001). Measuring population densities is therefore a necessary first step in establishing a plan to mitigate threats and subsequently assessing success of conservation action (Anderson et al. 2007; Chapman and Lambert 2000).

The types and magnitudes of threats faced by primates in unprotected landscapes can differ from those in protected areas (Tranquilli et al. 2014). Most data on primate abundance come from protected areas, however, which are often selected for surveying owing to high primate densities or the presence of charismatic taxa (e.g., great apes; Chapman and Peres 2001; Tranquilli et al. 2014). Assessing only a subset of a species' distribution may overestimate the importance of protected areas and underrepresent the role of unprotected areas that host large, often unmonitored populations. This risk is especially pertinent for relatively uncharismatic animals or species that live naturally at low densities (Cronon 1996; Gardner et al. 2007). Many studies also report intersite variation in human activities and interspecific variation in primate responses to threats (Estrada et al. 2017; Marsh and Chapman 2013). As such, conclusions from a single species or geographic area are not always applicable to other taxa or regions (AlmeidaRocha et al. 2017). To account for spatial heterogeneity of primate abundance and threats, data collected from landscape-scale surveys and protected area-level gradients should better reflect species distribution and conservation status (Arroyo-Rodriguez and Fahrig 2014; Caro 1999; Cavada et al. 2016).

The Greater Mahale Ecosystem (Fig. 1) in western Tanzania is a landscape in which there is a paucity of data on regional variation in primate abundance and local threats (Caro et al. 2009; Piel and Stewart 2014). Seven cercopithecine and colobine species occur in the Greater Mahale Ecosystem: Doggett's blue or silver monkey (hereafter, blue monkey; Cercopithecus mitis doggetti), red-tailed (C. ascanius schmidti) and vervet monkeys (Chlorocebus pygerythrus), ashy red colobus (Piliocolobus tephrosceles), black-and-white colobus (C. angolensis), and olive (Papio anubis) and yellow baboons ( $P$. cynocephalus; see Methods). Chimpanzees (Pan troglodytes schweinfurthii) are also distributed throughout the region (Piel and Stewart 2014). Unlike relatively homogeneous, primarily forested environments, vegetation in the Greater Mahale Ecosystem is a mosaic of savanna-woodland with minimal riparian forest cover (Piel et al. 2015a). Data from the Issa Valley - the only long-term research site in the Greater Mahale Ecosystem outside of Mahale Mountains National Parkindicate that typically forest-dwelling species, such as $C$. ascanius, live at extremely low densities in these mosaics compared to forested sites (e.g., 4 individuals $/ \mathrm{km}^{2} ; c f$. 127 individuals $/ \mathrm{km}^{2}$ at Kibale, Uganda, Table I; Tapper et al. 2019; see also Piel et al. 2015a). However, except for an assessment of ashy red colobus in the southern half of the Greater Mahale Ecosystem (Moyer et al. 2006), there are no previous region-wide assessments of cercopithecine or colobine species abundance in the Greater Mahale Ecosystem and so the effect of vegetation cover on population density is not fully 
understood. More broadly, all species listed here are classified as Least Concern on the IUCN Red List, except for ashy red colobus (Table I). Lower densities in response to environment heterogeneity should increase local extinction risk for these species, especially in unprotected areas (Purvis et al. 2000). It is therefore unknown if these labels accurately reflect vulnerability in the Greater Mahale Ecosystem.

Human population growth in the Greater Mahale Ecosystem is extremely high (e.g., $4.2 \%$ annual increase from 2002 to 2012; cf. 2.7\% for Tanzania overall, Tanzania National Bureau of Statistics 2012). This trend is due partly to Mishamo refugee settlement, which was established in 1972 and consisted of one settlement of $>45,000$ people at the time of study (Piel et al. 2015a; Fig. 1). With increased human activity in the region, high rates of poaching and habitat loss are the main threats to primates (Moyer et al. 2006). The only national park in the Greater Mahale Ecosystem-Mahale Mountains National Park - is at risk of isolation from surrounding forest due to increasing agriculture and road construction around park borders (Itoh et al. 2011; Piel and Stewart 2014). Outside of Mahale, protected land consists of Village Forest Reserves, in which conservation is partially decentralized from national government and managed by local communities (e.g., villages; Wily 2001; Wily and Dewees 2001). While protected areas should preserve higher animal densities relative to partially or unprotected areas (Caro 1999; Stoner et al. 2007), previous assessments of the effectiveness of Village Forest Reserves in conserving wildlife are mixed

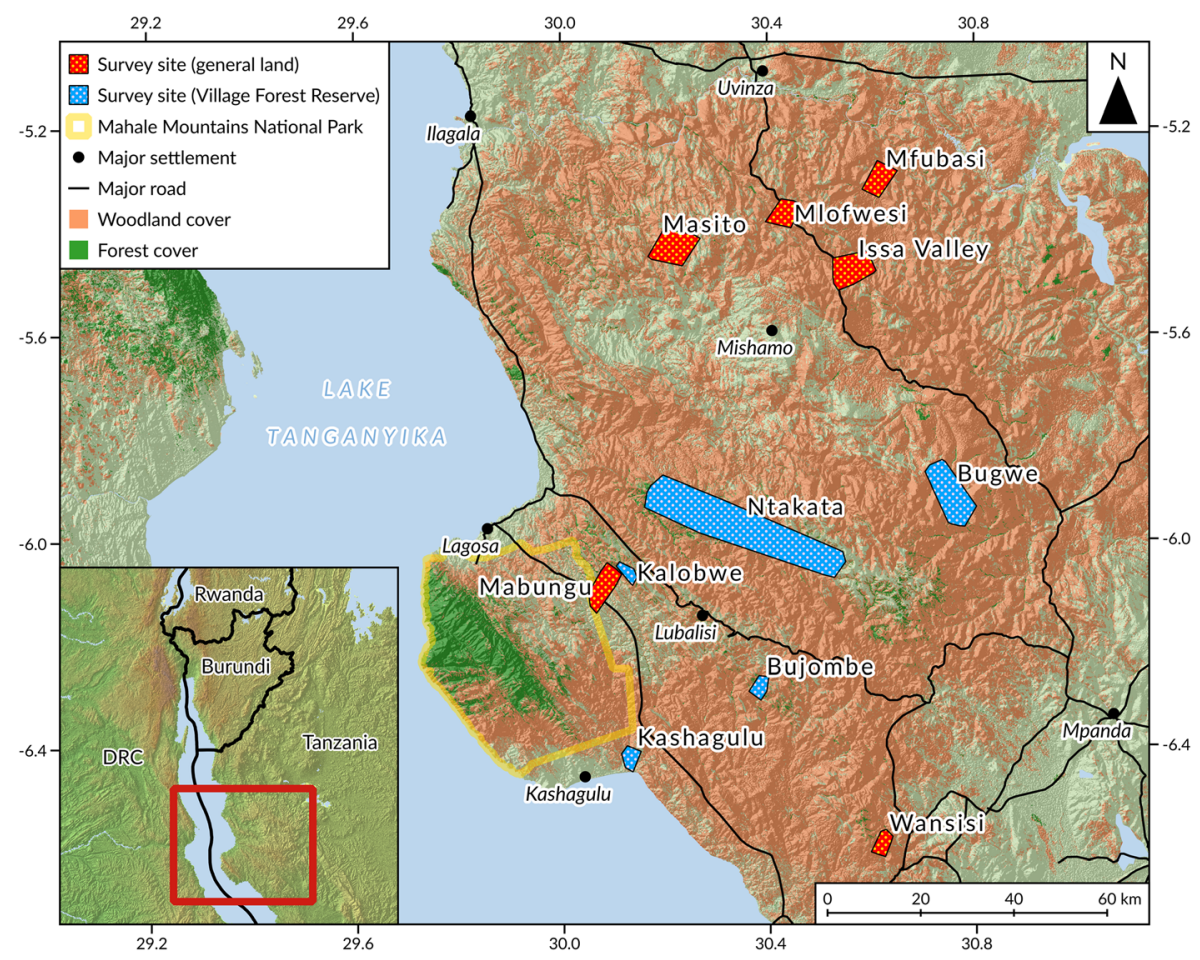

Fig. 1 Map of the Greater Mahale Ecosystem in western Tanzania. Minimum convex polygons surrounding all transects at each site are shown relative to the boundary of Mahale Mountains National Park and major settlements and roads in the region. 


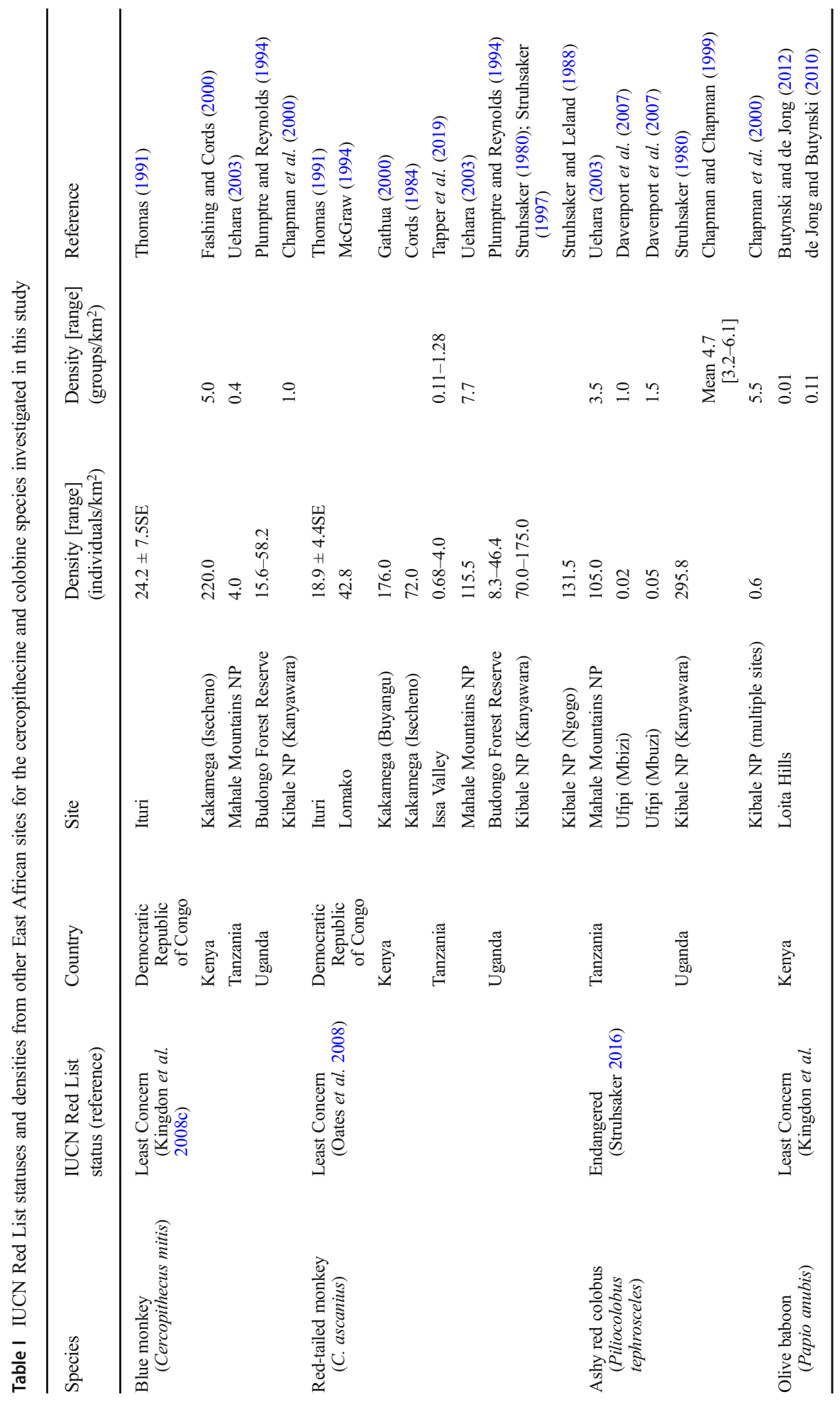




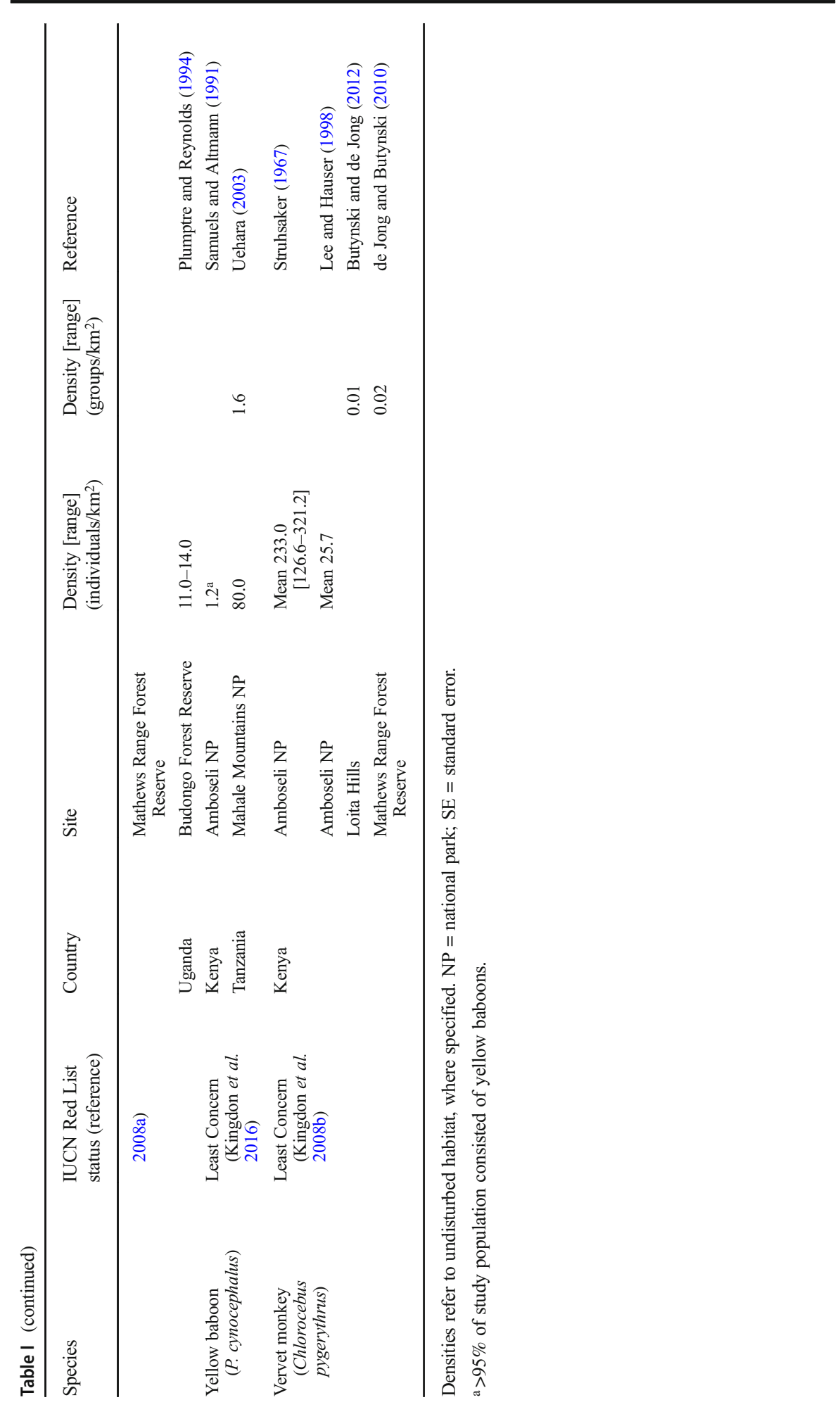


(reviewed in Brockington 2007; Ribot et al. 2010). Moreover, to our knowledge no study has yet quantitatively assessed primate abundance inside and outside of Village Forest Reserves (see Roe et al. 2009).

We surveyed 11 geographically independent sites in the Greater Mahale Ecosystem in 2011-2012 to estimate densities of cercopithecine and colobine species and human threats. We tested two hypotheses that could explain these densities. First, we hypothesized that densities are influenced by habitat quality, primarily by vegetation cover. Given a lack of prior data on almost all of our study species in forest-scarce mosaic habitat, we predicted that all primates across the region show lower densities than in more forested sites elsewhere. Second, we hypothesized that protected areas harbor greater primate densities than unprotected areas, in part due to reduced human threats. As such, we predicted Village Forest Reserves show higher primate densities and lower threat densities than unprotected, general land does.

\section{Methods}

\section{Study Area and Survey Sites}

The Greater Mahale Ecosystem is a $c a .18,200 \mathrm{~km}^{2}$ area bordered by the Malagarasi River to the north, the Ugalla River to the east, the southern border of Mahale Mountains National Park to the south, and Lake Tanganyika to the west (Fig. 1). Land cover is a mosaic of primarily miombo woodland, thin patches of riparian forest, larger patches of evergreen forest, and tracts of open grassland and seasonal swamps (Moyer et al. 2006). We collected data on monkey abundance during a landscape scale survey of chimpanzee habitat. We surveyed 10 different survey sites based on results from Conservation Action Planning workshops held during 2008-2010 that identified key areas for chimpanzee habitat (Piel and Stewart 2014; see Electronic Supplementary Material [ESM] Table SI for detailed descriptions). We conducted surveys from August 2011 to September 2012, and we also included data collected from January 2011 to December 2012 by the Greater Mahale Ecosystem Research and Conservation Project at the Issa Valley.

Sites were either Village Forest Reserves or general land with no formal protected status at the time of the surveys. Village Forest Reserves in the Greater Mahale Ecosystem are one designation of land under community-determined Village Land Use Plans, alongside zones set aside for residential buildings, agriculture, woodlots, etc. (Jane Goodall Institute 2009). This decentralization of conservation management aims to reduce conflict between communities and potentially distant national government (Wily and Dewees 2001). Specifically, these reserves are designed to allow forests to recover from overexploitation while encouraging shifts to sustainable resource extraction and livelihoods (e.g., ecotourism). As such, human activity in Village Forest Reserves is prohibited without village council permission, and several villages employ forest scouts or village forest monitors to actively police their reserves (Piel and Stewart 2014).

\section{Data Collection and Study Species}

At each site, two observers walked transects (range: 4-23 transects per site) of at least $1.2 \mathrm{~km}$ in length ( $\bar{x}: 4.3 \mathrm{~km}$; maximum: $7.3 \mathrm{~km}$; see ESM Table SI). At each site, we 
positioned an initial transect at the center of the area of interest, following a randomly selected 30 degrees bearing. We then positioned subsequent transects parallel to the initial transect at $c a$. 800-m intervals across the survey site. Observers walked each transect once at a pace of $1 \mathrm{~km} / \mathrm{h}$. At the Issa Valley, we walked a minimum of three $(\bar{x}: 6)$ of seven parallel transects distributed across the site at $0.3-1.2 \mathrm{~km}$ intervals every month except December 2011 as part of long-term data collection. On all transects, where we encountered obstacles (e.g., cliffs), we recorded the positions where we abandoned and resumed the transect and used the shortened length in analyses. AP and FS collected almost all data, trained field assistants at the Issa Valley in the protocol, and tested interobserver reliability to confirm that we did not need to control for observer variability in our analyses.

For each observation of primates or illegal human activity, we recorded perpendicular distance (from the transect to the center of the primate group or activity), group size, and vegetation class (see later). We measured perpendicular distances of $<10 \mathrm{~m}$ using a measuring tape and $>10 \mathrm{~m}$ using a Nikon Laser Rangefinder 550AS. We defined a primate group as multiple individuals of the same species in clearly observable close proximity, as per Buckland et al. (2010). We categorized vegetation classes as closed canopy riparian forest ( $\geq 50 \%$ connected canopy), open canopy riparian forest ( $<50 \%$ connected canopy), woodland, grassland, swamp, or converted land (road or cropland). We classified observations of human activity as one of three threat types reflecting increasing magnitudes of threat to primates: disturbance, hunting, or permanent land conversion (see ESM S1 for definitions; ESM Table SII).

We collected data on all cercopithecine and colobine species in the Greater Mahale Ecosystem except for black-and-white colobus, which are restricted to high-altitude forest in Mahale Mountains National Park (Moyer et al. 2006). In relation to baboons, Papio anubis are found only in the far north of the Greater Mahale Ecosystem, with most observations of phenotypically anubis-like animals in the Greater Mahale Ecosystem likely to be $P$. cynocehalus $\times P$. anubis hybrids. Phenotypically $P$. kindae-like baboons are found in Mahale Mountains National Park (Zinner et al. 2015) and as far north as the Issa Valley (AP unpubl. data; C. Jolly pers. comm.), although taxonomy remains unresolved in these areas (as per Zinner et al. 2015). Because we could not always reliably differentiate between $P$. cynocephalus, $P$. kindae, and hybrids, we grouped observations of any of these animals as "baboons."

\section{Line Transect Analyses}

Observation distances differed between vegetation classes because of variation in visibility. We recategorized vegetation classes into two habitat types: open habitat (open canopy riparian forest, woodland, grassland, swamp, and converted land) or closed habitat (closed canopy riparian forest). We used Distance 7.0 (Thomas et al. 2010) to calculate effective strip widths (ESW) separately for open and closed habitat across all sites combined by stratifying by habitat type.

We measured the length of each transect walked in open and closed habitat using AWiFS satellite imagery (see ESM S1 for details). We calculated densities by dividing the number of observations by area of open or closed habitat surveyed (area = length $\times$ $2 \mathrm{ESW}$ ) at each site. To control for the high variation in closed habitat cover between sites, we calculated densities using only the area for the habitat type occupied primarily ( $>75 \%$ observations in a single habitat type) by each species in the Greater Mahale 
Ecosystem (as per Caro 2001): closed habitat for red-tailed monkey, blue monkey, and ashy red colobus; open habitat for baboons and vervet monkey. We calculated single densities of each human activity for open and closed habitat combined. We condensed some observations of human activity because we could not always reliably count individual instances within a particular activity (e.g., we grouped any number of cattle in a herd as a single observation; see ESM Table SII).

\section{Statistical Analyses}

We used Mann-Whitney-Wilcoxon tests in R 3.5.1 (R Core Team 2018) to compare primate and human activity densities between Village Forest Reserves and unprotected sites ( $N=5$ Village Forest Reserves; $N=6$ unprotected sites; ESM Table SI). Given the low number of observations of any primate species, to provide a sufficient sample size we pooled densities for each of open and closed habitat species across all transects for each site. We excluded a single outlying value for closed habitat species at Bugwe. We tested for collinearity between primate density and proportion of forest cover across all sites because we expected Village Forest Reserves to be implemented in areas of higher forest cover than general land. There was no significant difference in forest cover in Village Forest Reserves compared to general land (Mann-Whitney $U$ test: $N=11$ sites, $U=6.000, P=0.126)$. Forest cover was correlated with closed habitat species density (Kendall tau-b correlation: $\tau=0.601, P=0.012$ ) and open habitat species density $(\tau=$ $-0.554, P=0.032$ ). We therefore weighted densities by proportions of open and closed habitat cover at each site for open and closed habitat species, respectively.

\section{Ethical Note}

We collected data with permission from the Tanzania Wildlife Research Institute (TAWIRI), the Tanzanian Commission for Science and Technology (COSTECH), and Kigoma and Mpanda district governments; and in accordance with all applicable guidelines for the observation of wild animals in Tanzania. The authors declare that they have no conflict of interest.

Data Availability The data analyzed in this study are available from the corresponding author on reasonable request.

\section{Results}

We observed each of our study species on at least one occasion (Table II). Except for blue monkeys, which we observed at only one site (Ntakata), we observed each species at a minimum of two survey sites (maximum: six sites for ashy red colobus). There was no site with observations of all five species (maximum: four species at the Issa Valley), and at two sites (Kashagulu and Masito) we did not observe any species. The highest densities we observed were shown by red colobus at Bujombe (67.1 individuals and 4.3 groups/ $\mathrm{km}^{2}$; Table II) and Bugwe (outlying values: 209.1 individuals and 26.1 groups $/ \mathrm{km}^{2}$ ). Vervet monkeys and baboons showed the lowest maximum densities across all sites $(0.2$ 
and 7.5 individuals $/ \mathrm{km}^{2}$ at Mabungu and Bugwe, respectively), followed by blue monkeys (10.4 individuals $/ \mathrm{km}^{2}$ at Ntakata) and red-tailed monkeys (32.3 individuals/ $\mathrm{km}^{2}$ at the Issa Valley). Densities (individuals $/ \mathrm{km}^{2}$ ) were substantially lower for each species than those reported at other sites (Table I). Neither densities for closed habitat nor open habitat species pooled (individuals $/ \mathrm{km}^{2}$ ) differed significantly between Village Forest Reserves or general land sites (Mann-Whitney-Wilcoxon tests: $N=11$ sites; open habitat species: $Z=0.995, P=0.320$; closed habitat species: $Z=-0.910, P=0.363$ ).

We observed human activity at all 11 sites (Table III). The most widespread threat we observed was evidence of habitat disturbance, which was found at all but one site (Kalobwe). Similarly, evidence of land conversion was observed at all but two sites (Issa and Kashagulu). Evidence of hunting was the least frequently encountered threat. We observed evidence of hunting at only 6 of 11 sites, and densities were also substantially lower than the other threat types (Fig. 2). Similar to primate densities, densities of either threat type (observations $/ \mathrm{km}^{2}$ ) did not differ significantly with protected status (Mann-Whitney-Wilcoxon tests: $N=11$ sites; disturbance: $Z=1.095$, $P=0.273$; hunting: $Z=1.869, P=0.062$; land conversion: $Z=1.095, P=0.273$ ).

\section{Discussion}

We found cercopithecine and colobine densities across the Greater Mahale Ecosystem to be lower across both protected and unprotected areas compared with numbers reported from tropical forests, in line with our first prediction. Our findings corroborate previous studies from the Issa Valley that found forest-dwelling primate species living at lower densities compared to forest-dominated landscapes (e.g., Piel et al. 2015a). This is likely due mostly to the low proportion of riparian forest cover in savannawoodland mosaics, which results in a wider distribution of resources for forest primates compared to predominantly forested environments (Isbell and Young 1996). Consequently, lower food availability may constrain densities of these species (Hemingway and Bynum 2005; Piel et al. 2017). For example, similar low densities reported for redtailed monkeys at the Issa Valley and chimpanzees in the Greater Mahale Ecosystem are associated with large home ranges that are required to meet daily nutritional requirements from patchily distributed food (Ogawa et al. 2007; Tapper et al. 2019).

Interspecific competition and predation pressure also influence population densities (Chapman et al. 2004). For example, monkeys compete with chimpanzees for woodland and riparian forest foods at the Issa Valley (Piel et al. 2017). In addition, chimpanzees are known to prey upon red-tailed, blue, and red colobus monkeys at primarily forested sites, e.g., Gombe, Tanzania (Wrangham and van Zinnicq Bergmann Riss 1990) and Kibale, Uganda (Watts and Mitani 2002). While increased chimpanzee abundance could be expected to constrain monkey densities, chimpanzee densities reported by at each site broadly reflect the densities we observed for monkeys (Piel and Stewart 2014). Specifically, Ntakata, Kalobwe, and Bujombe - the three sites with the highest proportions of riparian forest — had the highest chimpanzee densities and comprised three of the four sites from this study with the highest densities of closed habitat species overall. Interspecific differences in abundance may therefore relate more strongly to the extent of suitable habitat for these primates in the Greater Mahale Ecosystem. Primate communites typically show high species nestedness as suitable habitat increases in area (Irwin 2016). For forest 


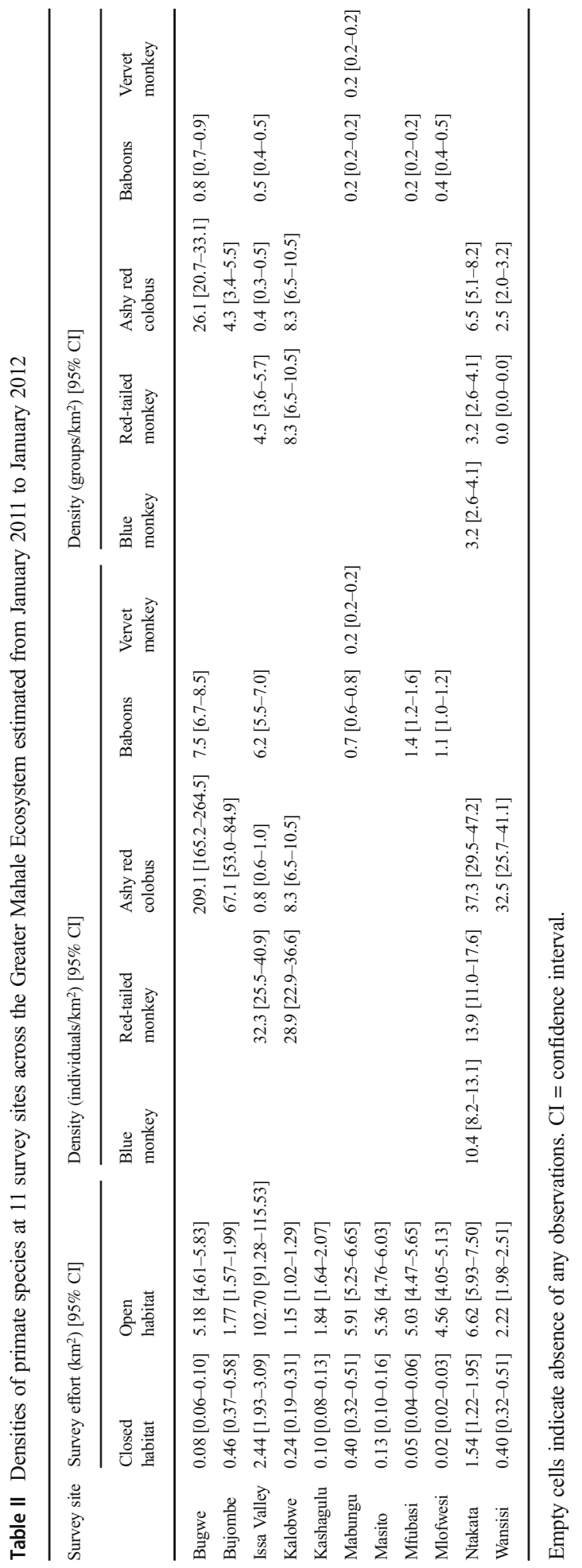


primates, this effect may constrain densities in a heterogeneous, mosaic environment where suitable habitat should be smaller in area, more patchily distributed, and offer lower quality food compared to forests (Piel et al. 2017; Tapper et al. 2019).

Densities (individuals $/ \mathrm{km}^{2}$ ) for baboons and vervet monkeys were also low compared to other sites outside of the Greater Mahale Ecosystem (Table I). A lack of resources is less likely to explain these differences given that vegetation in the Greater Mahale Ecosystem is much more typical for these species than for forest monkeys. Although disturbance could explain low densities, both baboons and vervet monkeys are known to be highly adaptable to human presence (Hill 2000). While we did not observe high rates of hunting in the Greater Mahale Ecosystem, given that hunting is pervasive in other areas of western and southwestern Tanzania (e.g., Davenport et al. 2007; Mgawe et al. 2012), the complete absence of these animals at many sites could indicate previous extirpation or shifts to hunting tactics that leave fewer evidence behind (e.g., with guns; $c f$. snares, Piel et al. 2015b).

Low densities suggest that forest-dwelling monkeys are likely more vulnerable to human threats than in areas supporting higher densities (Purvis et al. 2000). Specifically, we found evidence of a decline in abundance for ashy red colobus - the most endangered species we investigated and the only species for which a previous density in the Greater Mahale Ecosystem is available. Moyer et al. (2006) calculated a mean density of 74.6 individuals $/ \mathrm{km}^{2}$ for ashy red colobus from surveys conducted in 2005 across Ntakata, Wansisi, and additional sites south and southwest of Mishamo (Fig. 1); over double our average of 32.3 individuals $/ \mathrm{km}^{2}$. This decline could be due to poor behavioral flexibility in the face of increased human pressure. Forest-adapted primates like colobus monkeys that have much larger home ranges in savanna-mosaics may be especially vulnerable to habitat degradation and should therefore be slow to shift ranges to undisturbed areas (Irwin 2016) or recover if degradation stops (Chapman et al. 2000; Isaac and Cowlishaw 2004). Moreover, vegetation type influences species susceptibility to threats. In forests, primates are particularly vulnerable to land conversion that reduces tree cover, while in woodlands and grasslands, primates are more easily hunted or ensnared (Isaac and Cowlishaw 2004; Kümpel et al. 2008). In heterogeneous environments, primates that utilize multiple vegetation types, e.g., red-tailed monkeys (McLester et al. 2018; Tapper et al. 2019), should therefore encounter a greater diversity of threats, which may exacerbate population decline.

We observed higher rates of indirect threats (e.g., disturbance) than direct threats (e.g., hunting and land conversion). All of our study species show some resilience to habitat disturbance. For example, olive baboons in Kenya preferentially follow roads (Strandburg-Peshkin et al. 2017) and vervet monkeys in Uganda forage on crops with relatively low rates of retaliatory killing by farmers (Saj et al. 2001). Resilience may also delay short-term declines in forest primate densities (red-tailed monkeys, red colobus: Struhsaker 1997; blue monkeys: Mammides et al. 2009) or lead to temporarily increased densities (e.g., Colobus guereza: Fashing 2002; C. angolensis palliatus: Marshall et al. 2005). These trends may be partly due to preference by these species for food in secondary vegetation that results from logging (Mammides et al. 2009; Thomas 1991). Nonetheless, red colobus and red-tailed and blue monkeys show wide intraspecific variation in these responses (e.g., Chapman et al. 2000; Plumptre and Reynolds 1994), possibly as the result of habitat-specific dietary flexibility (Nowak and Lee 2013). Furthermore, even though primates in the Greater Mahale Ecosystem that 


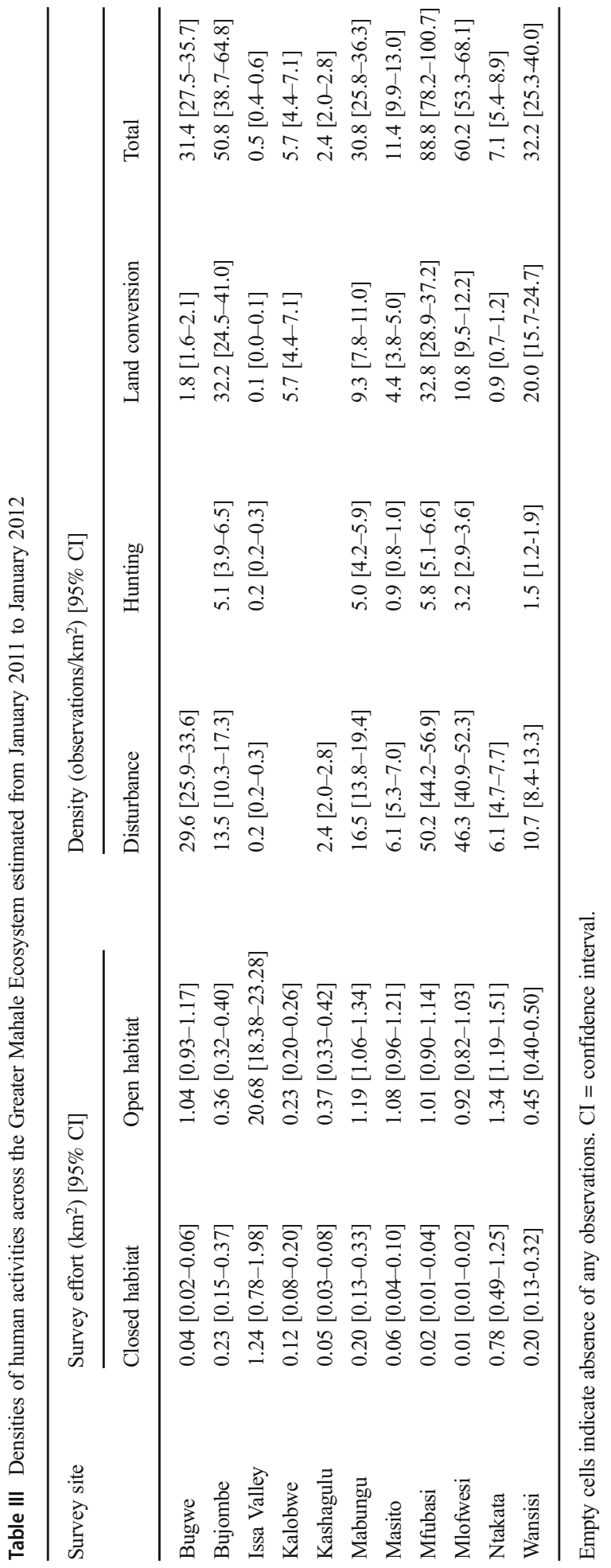



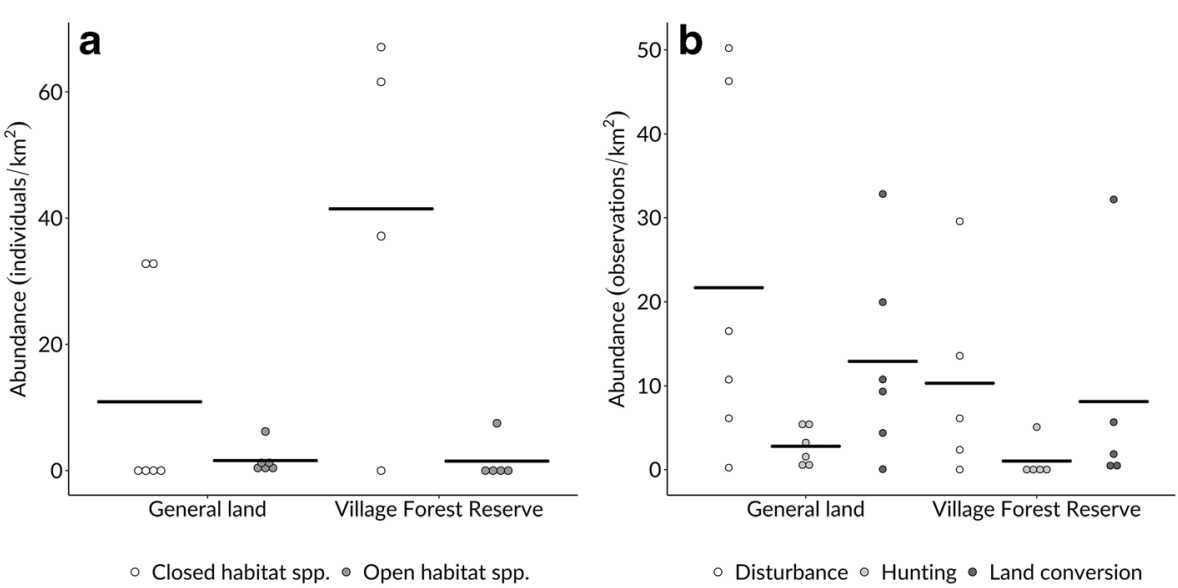

Fig. 2 Variation in densities of open and closed habitat species (a) and human activities (b) between general land and Village Forest Reserves across the Greater Mahale Ecosystem estimated from January 2011 to January 2012. Black horizontal lines indicate mean values.

exploit both forest and woodland foods (e.g., Tapper et al. 2019) could therefore be expected to tolerate disturbed habitat for longer than forest populations, previous studies have demonstrated disproportionate increases in habitat degradation following even low levels of initial disturbance (the "Pandora's Box Effect": Laurance et al. 2009). Resilience to human activity is therefore unlikely to lead to long-term population survival in the Greater Mahale Ecosystem, particularly if rates and intensities of habitat degradation will only increase over time (Nowak and Lee 2013).

We did not find formal protection to result in significantly higher primate densities, in contrast to our prediction. Forest primate densities are expected to be low in mosaic environments, which complicates conservation strategies. Specifically, discerning whether these species are well adapted and naturally surviving at low densities, or instead experiencing population decline and therefore severely at risk, will require rigorous and standardized long-term monitoring (Chapman et al. 2000). In the Greater Mahale Ecosystem, the need for continuous monitoring is particularly high because of the infrequency of surveys thus far. For example, the densities we report in this study are at least $7 \mathrm{yr}$ old, and given high rates of habitat degradation and human encroachment in the region, these numbers may overestimate actual species abundances at the time of publication.

The absence of many species in both protected and unprotected areas may also explain a lack of significant difference without indicating an ineffectiveness of Village Forest Reserves. Specifically, absences may reflect the challenges of surveying monkeys that require direct observations to be identified (e.g., in contrast to chimpanzees, which are identifiable from nests or relatively conspicuous scat). For example, redtailed and blue monkeys typically produce only sporadic vocalizations (e.g., male "pyows" and "pops") or hide in silence in response to potential predators passing below (Detwiler 2010). Substantial variation in forest monkey group size and spread between savanna-woodland mosaics and forests may also influence observation rates in these environments (as per Plumptre 2000; e.g., see McLester et al. 2019). Moreover, transects were designed with the primary aim of investigating evidence of chimpanzee presence in both open and closed vegetation. While forest monkeys do use open vegetation in the Greater Mahale Ecosystem, they typically remain close to forest 
edges and retreat into forest in response to humans or predators. As such, even though we controlled for forest proportions when calculating densities, time spent in large tracts of open vegetation likely reduced opportunities for observing forest monkeys. Future surveys should repeat transect walks, particularly in forest patches, to maximize search effort (e.g., as recommended by Teelen 2007), while analyses should control for habitat-specific patterns of group size and spread, where known.

Village Forest Reserve status did not have a significant effect in deterring human encroachment. Instead, we found the lowest levels of human activity at the Issa Valley. Given the permanent research station at this site, this result further suggests that researcher presence can deter habitat encroachment (Campbell et al. 2011; Laurance 2013; Piel et al. 2015b). The Issa Valley is the closest buffer to expansion of Mishamo and a continued researcher presence will likely be integral to future conservation in this area. Nonetheless, researcher presence alone is unlikely to replace large-scale protected areas and if well funded and actively enforced, protected areas remain important strategies in conserving wildlife (Tranquilli et al. 2014).

Strengthening enforcement of existing Village Forest Reserves and implementing new reserves in the Greater Mahale Ecosystem were priorities for recent Conservation Action Planning workshops (TANAPA 2015). More data on Village Forest Reserve management, ideally obtained directly from local communities, are needed to recommend appropriate improvements for current Village Forest Reserves in the Greater Mahale Ecosystem. Similarly, locations and types of reserves are best determined by benefits that should be identified for local communities as well as wildlife (Geldmann et al. 2013; Salerno et al. 2015). Devolving conservation management to the village level through Village Forest Reserves remains a relatively recent (1998) concept in Tanzania (e.g., compared to the national park system; Wily and Dewees 2001). Given previously identified risks of Village Forest Reserve mismanagement (e.g., increased corruption; Brockington 2007), these reserves require careful administration in their infancy if they are to provide long-term benefits to people and wildlife alike. In the meantime, unprotected land that remains undisturbed seems likely to become increasingly important refuges for primates in the Greater Mahale Ecosystem if human encroachment into primate habitat continues to increase. As such, our results provide a starting point from which long-term trends in primate abundance and human activity in the Greater Mahale Ecosystem can be established and furthermore reinforce the need for continuous monitoring both inside and outside of protected areas to inform the most effective conservation strategies for primate populations in this region.

Acknowledgments We thank the Tanzanian Wildlife Research Institute (TAWIRI), the Tanzanian Commission for Science and Technology (COSTECH), and Kigoma and Mpanda District governments for permission to conduct research in Tanzania. The GMERC Project is supported by the UCSD/Salk Center for Academic Research and Training in Anthropogeny (CARTA). This work was cofunded by the ARCUS Foundation and the United States Fish and Wildlife Service. The Nature Conservancy, Frankfurt Zoological Society, the United States Agency for International Development, and The Jane Goodall Institute, USA provided financial, logistical, and administrative support, and Leslie Knapp and the Division of Biological Anthropology at the University of Cambridge provided field supplies and equipment. We thank field assistants for help with data collection, Noémie Bonnin for providing population data, Addisu Mekonnen and two anonymous reviewers for comments on a previous revision of this manuscript, and Kate Detwiler and Reiko Matsuda Goodwin for the invitation to first present results as part of the Current Research and Conservation of the African Monkeys symposium at the 2016 joint IPS/ASP meeting. 
Author Contributions AP and FS conceived the study and developed methodology. AP, FS, and LP collected data. EM analyzed the data and wrote the manuscript; other authors provided editorial advice.

Open Access This article is licensed under a Creative Commons Attribution 4.0 International License, which permits use, sharing, adaptation, distribution and reproduction in any medium or format, as long as you give appropriate credit to the original author(s) and the source, provide a link to the Creative Commons licence, and indicate if changes were made. The images or other third party material in this article are included in the article's Creative Commons licence, unless indicated otherwise in a credit line to the material. If material is not included in the article's Creative Commons licence and your intended use is not permitted by statutory regulation or exceeds the permitted use, you will need to obtain permission directly from the copyright holder. To view a copy of this licence, visit http://creativecommons.org/licenses/by/4.0/.

\section{References}

Almeida-Rocha, J. M. d., Peres, C. A., \& Oliveira, L. C. (2017). Primate responses to anthropogenic habitat disturbance: A pantropical meta-analysis. Biological Conservation, 215, 30-38.

Anderson, J., Cowlishaw, G., \& Rowcliffe, J. M. (2007). Effects of forest fragmentation on the abundance of Colobus angolensis palliatus in Kenya's coastal forests. International Journal of Primatology, 28(3), 637-655.

Arroyo-Rodriguez, V., \& Fahrig, L. (2014). Why is a landscape perspective important in studies of primates? American Journal of Primatology, 76(10), 901-909.

Brockington, D. (2007). Forests, community conservation, and local government performance: The Village Forest Reserves of Tanzania. Society \& Natural Resources, 20(9), 835-848.

Buckland, S. T., Plumptre, A. J., Thomas, L., \& Rexstad, E. A. (2010). Design and analysis of line transect surveys for primates. International Journal of Primatology, 31(5), 833-847.

Butynski, T. M., \& de Jong, Y. A. (2012). Survey of the primates of the Loita Hills, Kenya. Report submitted to Eastern Africa Primate Diversity and Conservation Program, Kenya.

Campbell, G., Head, J., Junker, J., \& Nekaris, A. K. I. (2016). Primate abundance and distribution: Background concepts and methods. In S. Wich \& A. J. Marshall (Eds.), An introduction to primate conservation (pp. 79-110). Oxford: Oxford University Press.

Campbell, G., Kuehl, H., Diarrassouba, A., N'Goran, P. K., \& Boesch, C. (2011). Long-term research sites as refugia for threatened and over-harvested species. Biology Letters, 7(5), 723-726.

Caro, T., Jones, T., \& Davenport, T. R. B. (2009). Realities of documenting wildlife corridors in tropical countries. Biological Conservation, 142(11), 2807-2811.

Caro, T. M. (1999). Densities of mammals in partially protected areas: The Katavi ecosystem of western Tanzania. Journal of Applied Ecology, 36, 205-217.

Caro, T. M. (2001). Species richness and abundance of small mammals inside and outside an African national park. Biological Conservation, 98, 251-257.

Cavada, N., Barelli, C., Ciolli, M., \& Rovero, F. (2016). Primates in human-modified and fragmented landscapes: The conservation relevance of modelling habitat and disturbance factors in density estimation. PLOS ONE, 11(2), e0148289.

Chapman, C. A., Balcomb, S. R., Gillespie, T. R., Skorupa, J. P., \& Struhsaker, T. T. (2000). Long-term effects of logging on African primate communities: A 28-year comparison from Kibale National Park, Uganda. Conservation Biology, 14(1), 207-217.

Chapman, C. A., \& Chapman, L. J. (1999). Implications of small scale variation in ecological conditions for the diet and density of red colobus monkeys. Primates, 40(1), 215-231.

Chapman, C. A., Chapman, L. J., Naughton-Treves, L., Lawes, M. J., \& McDowell, L. R. (2004). Predicting folivorous primate abundance: Validation of a nutritional model. American Journal of Primatology, 62, 55-69.

Chapman, C. A., \& Lambert, J. E. (2000). Habitat alteration and the conservation of African primates: Case study of Kibale National Park, Uganda. American Journal of Primatology, 50, 169-185.

Chapman, C. A., \& Peres, C. A. (2001). Primate conservation in the new millennium: The role of scientists. Evolutionary Anthropology, 10, 16-33.

Cords, M. (1984). Mating patterns and social structure in redtail monkeys (Cercopithecus ascanius). Zeitschrift für Tierpsychologie, 64, 313-329. 
Cronon, W. (1996). The trouble with wilderness: Or, getting back to the wrong nature. Environmental History, 1(1), 7-28.

Davenport, T. R. B., Mpunga, N. E., \& Machaga, S. J. (2007). Census and conservation assessment of the red colobus (Procolobus rufomitratus tephrosceles) on the Ufipa Plateau, southwest Tanzania: Newlydiscovered, threatened and extinct populations. Primate Conservation, 22(1), 97-105.

de Jong, Y. A., \& Butynski, T. M. (2010). Assessment of the primates, large mammals and birds of the Mathews Range Forest Reserve, Central Kenya. Report submitted to The Nature Conservancy, Washington, DC.

Detwiler, K. (2010). Natural hybridization between Cercopithecus mitis $\times$ C. ascanius in Gombe National Park, Tanzania. Doctoral dissertation, New York University.

Estrada, A., Garber, P. A., Rylands, A. B., Roos, C., Fernandez-Duque, E., et al (2017). Impending extinction crisis of the world's primates: Why primates matter. Science Advances, 3(1), 1-16.

Fashing, P. J. (2002). Population status of black and white colobus monkeys (Colobus guereza) in Kakamega Forest, Kenya: Are they really on the decline? African Zoology, 37(2), 119-126.

Fashing, P. J., \& Cords, M. (2000). Diurnal primate densities and biomass in the Kakamega Forest: An evaluation of census methods and a comparison with other forests. American Journal of Primatology, 50, $139-152$.

Gardner, T. A., Caro, T., Fitzherbert, E. B., Banda, T., \& Lalbhai, P. (2007). Conservation value of multipleuse areas in East Africa. Conservation Biology, 21(6), 1516-1525.

Gathua, J. M. (2000). Intraspecific variation in foraging patterns of redtail monkeys (Cercopithecus ascanius) in the Kakamega Forest, Kenya. Doctoral dissertation, Columbia University.

Geldmann, J., Barnes, M., Coad, L., Craigie, I. D., Hockings, M., \& Burgess, N. D. (2013). Effectiveness of terrestrial protected areas in reducing habitat loss and population declines. Biological Conservation, 161, 230-238.

Gillespie, T. R., \& Chapman, C. A. (2008). Forest fragmentation, the decline of an endangered primate, and changes in host-parasite interactions relative to an unfragmented forest. American Journal of Primatology, $70(3), 222-230$.

Hemingway, C. A., \& Bynum, N. (2005). The influence of seasonality on primate diet and ranging. In D. K. Brockman \& C. P. van Schaik (Eds.), Seasonality in primates: Studies of living and extinct human and non-human primates (pp. 57-104). Cambridge: Cambridge University Press.

Hill, C. M. (2000). Conflict of interest between people and baboons: Crop raiding in Uganda. International Journal of Primatology, 21(2), 299-315.

Irwin, M. (2016). Habitat change: Loss, fragmentation and degradation. In S. Wich \& A. J. Marshall (Eds.), An introduction to primate conservation (pp. 111-127). Oxford: Oxford University Press.

Isaac, N. J., \& Cowlishaw, G. (2004). How species respond to multiple extinction threats. Proceedings of the Royal Society B: Biological Sciences, 271(1544), 1135-1141.

Isbell, L. A., \& Young, T. P. (1996). The evolution of bipedalism in hominids and reduced group size in chimpanzees: Alternative responses to decreasing resource availability. Journal of Human Evolution, 30, 389-397.

Itoh, N., Nakamura, M., Ihobe, H., Uehara, S., Zamma, K., et al (2011). Long-term changes in the social and natural environments surrounding the chimpanzees of Mahale Mountains National Park. In A. J. Plumptre (Ed.), The ecological impact of long-term changes in Africa's Rift Valley (pp. 211-235). New York: Nova Science Publishers.

Jane Goodall Institute. (2009). Landscape-scale community-centered ecosystem conservation in western Tanzania. Report submitted to U.S. Agency for International Development/Tanzania.

Kingdon, J., Butynski, T. M., \& De Jong, Y. (2008a). Papio anubis. The IUCN Red List of Threatened Species 2008. https://doi.org/10.2305/IUCN.UK.2008.RLTS.T40647A10348950.en (accessed July 2, 2019).

Kingdon, J., Butynski, T. M., \& De Jong, Y. (2016). Papio cynocephalus. The IUCN Red List of Threatened Species 2008. https://doi.org/10.2305/IUCN.UK.2016-1.RLTS.T92250442A92250811.en (accessed July 2, 2019).

Kingdon, J., Gippoliti, S., Butynski, T. M., \& De Jong, Y. (2008b). Chlorocebus pygerythrus. The IUCN Red List of Threatened Species 2008. https://doi.org/10.2305/IUCN.UK.2008.RLTS.T136271A4267738.en (accessed July 2, 2019).

Kingdon, J., Gippoliti, S., Butynski, T. M., Lawes, M. J., Eeley, H., et al. (2008c). Cercopithecus mitis ssp. doggetti. The IUCN Red List of Threatened Species 2008. https://doi.org/10.2305/IUCN.UK.2008.RLTS. T136861A4347475.en (accessed July 2, 2019).

Kümpel, N. F., Milner-Gulland, E. J., Rowcliffe, J. M., \& Cowlishaw, G. (2008). Impact of gun-hunting on diurnal primates in continental Equatorial Guinea. International Journal of Primatology, 29(4), 10651082. 
Laurance, W. F. (2013). Does research help to safeguard protected areas? Trends in Ecology and Evolution, 28(5), 261-266.

Laurance, W. F., Goosem, M., \& Laurance, S. G. (2009). Impacts of roads and linear clearings on tropical forests. Trends in Ecology and Evolution, 24(12), 659-669.

Lawton, J. H. (1993). Range, population abundance and conservation. Trends in Ecology and Evolution, 8(11), $409-413$.

Lee, P. C., \& Hauser, M. D. (1998). Long-term consequences of changes in territory quality on feeding and reproductive strategies of vervet monkeys. Journal of Animal Ecology, 67(3), 347-358.

Mammides, C., Cords, M., \& Peters, M. K. (2009). Effects of habitat disturbance and food supply on population densities of three primate species in the Kakamega Forest, Kenya. African Journal of Ecology, 47, 87-96.

Marsh, L. K., \& Chapman, C. A. (2013). Primates in fragments: Complexity and resilience. Developments in Primatology: Progress and Prospects. New York: Springer Science+Business Media.

Marshall, A. R., Topp-Jørgensen, J. E., Brink, H., \& Fanning, E. (2005). Monkey abundance and social structure in two high-elevation forest reserves in the Udzungwa Mountains of Tanzania. International Journal of Primatology, 26(1), 127-145.

McGraw, S. (1994). Census, habitat preference, and polyspecific associations of six monkeys in the Lomako Forest, Zaire. American Journal of Primatology, 34(4), 295-307.

McLester, E., Brown, M., Stewart, F. A., \& Piel, A. K. (2019). Food abundance and weather influence habitatspecific ranging patterns in forest- and savanna mosaic-dwelling red-tailed monkeys (Cercopithecus ascanius). American Journal of Physical Anthropology, 170(2), 217-231.

McLester, E., Sweeney, K., Stewart, F. A., \& Piel, A. K. (2018). Leopard (Panthera pardus) predation on a red-tailed monkey (Cercopithecus ascanius) in the Issa Valley, western Tanzania. Primates, 60(1), 15-19.

Mgawe, P., Borgerhoff Mulder, M., Caro, T., Martin, A., \& Kiffner, C. (2012). Factors affecting bushmeat consumption in the Katavi-Rukwa ecosystem of Tanzania. Tropical Conservation Science, 5(4), 446-462.

Moyer, D., Plumptre, A. J., Pintea, L., Hernandez-Aguilar, A., Moore, J., et al. (2006). Surveys of chimpanzees and other biodiversity in western Tanzania. Report submitted to USF\&W, Great Apes Fund.

Nowak, K., \& Lee, P. C. (2013). "Specialist” primates can be flexible in response to habitat alteration. In L. K. Marsh \& C. A. Chapman (Eds.), Primates in fragments: Complexity and resilience (pp. 199-211). Developements in Primatology: Progress and Prospects. New York: Springer Science+Business Media.

Oates, J. F., Hart, J., Groves, C. P., \& Butynski, T. M. (2008). Cercopithecus ascanius ssp. schmidti. The IUCN Red List of Threatened Species 2008. https://doi.org/10.2305/IUCN.UK.2008.RLTS.T136917 A4349878.en (accessed July 2, 2019).

Ogawa, H., Idani, G., Moore, J., Pintea, L., \& Hernandez-Aguilar, A. (2007). Sleeping parties and nest distribution of chimpanzees in the savanna woodland, Ugalla, Tanzania. International Journal of Primatology, 28(6), 1397-1412.

Pearce, J., \& Ferrier, S. (2001). The practical value of modelling relative abundance of species for regional conservation planning: A case study. Biological Conservation, 98(1), 33-43.

Piel, A. K., Cohen, N., Kamenya, S., Ndimuligo, S. A., Pintea, L., \& Stewart, F. A. (2015a). Population status of chimpanzees in the Masito-Ugalla Ecosystem, Tanzania. American Journal of Primatology, 77(10), 1027-1035.

Piel, A. K., Lenoel, A., Johnson, C., \& Stewart, F. A. (2015b). Deterring poaching in western Tanzania: The presence of wildlife researchers. Global Ecology and Conservation, 3, 188-199.

Piel, A. K., \& Stewart, F. A. (2014). Census and conservation status of chimpanzees (Pan troglodytes schweinfurthii) across the Greater Mahale Ecosystem, 2011-2012. Report submitted to The Nature Conservancy, Washington, DC.

Piel, A. K., Strampelli, P., Greathead, E., Hernandez-Aguilar, R. A., Moore, J., \& Stewart, F. A. (2017). The diet of open-habitat chimpanzees (Pan troglodytes schweinfurthii) in the Issa valley, western Tanzania. Journal of Human Evolution, 112, 57-69.

Plumptre, A. J. (2000). Monitoring mammal populations with line transect techniques in African forests. Journal of Applied Ecology, 37, 356-368.

Plumptre, A. J., \& Johns, A. G. (2001). Changes in primate communities following logging disturbance. In R. A. Fimbel, A. Grajal, \& J. G. Robinson (Eds.), The cutting edge: Conserving wildlife in logged tropical forests (pp. 71-92). New York: Columbia University Press.

Plumptre, A. J., \& Reynolds, V. (1994). The effect of selective logging on the primate populations in the Budongo Forest Reserve, Uganda. Journal of Applied Ecology, 31, 631-641.

Purvis, A., Gittleman, J. L., Cowlishaw, G., \& Mace, G. M. (2000). Predicting extinction risk in declining species. Proceedings of the Royal Society B: Biological Sciences, 267(1456), 1947-1952. 
R Core Team (2018). R: A language and environment for statistical computing. Vienna, Austria: R Foundation for Statistical Computing https:/www.R-project.org/.

Ribot, J. C., Lund, J. F., \& Treue, T. (2010). Democratic decentralization in sub-Saharan Africa: Its contribution to forest management, livelihoods, and enfranchisement. Environmental Conservation, $37(1), 35-44$.

Roe, D., Nelson, F., \& Sandbrook, C. (2009). Community management of natural resources in Africa: Impacts, experiences and future directions. Natural Resource Issues No. 18. London: International Institute for Environment and Development.

Saj, T. L., Sicotte, P., \& Paterson, J. D. (2001). The conflict between vervet monkeys and farmers at the forest edge in Entebbe, Uganda. African Journal of Ecology, 39, 195-199.

Salerno, J., Borgerhoff Mulder, M., Grote, M. N., Ghiselli, M., \& Packer, C. (2015). Household livelihoods and conflict with wildlife in community-based conservation areas across northern Tanzania. Oryx, 50(04), 702-712.

Samuels, A., \& Altmann, J. (1991). Baboons of the Amboseli Basin: Demographic stability and change. International Journal of Primatology, 12(1), 1-19.

Statistics, T. N. B. o. (2012). 2012 Population and Housing Census. Online database available at https://www. nbs.go.tz/index.php/en/ (accessed July 29, 2019).

Stoner, C., Caro, T., Mduma, S., Mlingwa, C., Sabuni, G., \& Borner, M. (2007). Assessment of effectiveness of protection strategies in Tanzania based on a decade of survey data for large herbivores. Conservation Biology, 21(3), 635-646.

Strandburg-Peshkin, A., Farine, D. R., Crofoot, M. C., \& Couzin, I. D. (2017). Habitat and social factors shape individual decisions and emergent group structure during baboon collective movement. Elife, 6 .

Struhsaker, T. (2016). Piliocolobus tephrosceles. The IUCN Red List of Threatened Species 2008. https://doi. org/10.2305/IUCN.UK.2016-1.RLTS.T18256A92660998.en (accessed July 2, 2019).

Struhsaker, T. T. (1967). Ecology of vervet monkeys (Cercopithecus aethiops) in the Masai-Amboseli Game Reserve, Kenya. Ecology, 48(6), 891-904.

Struhsaker, T. T. (1980). Comparison of the behaviour and ecology of red colobus and redtail monkeys in the Kibale Forest, Uganda. African Journal of Ecology, 18, 33-51.

Struhsaker, T. T. (1997). Ecology of an African rainforest. Gainesville, FL: University of Florida Press.

Struhsaker, T. T., \& Leland, L. (1988). Group fission in redtail monkeys (Cercopithecus ascanius) in the Kibale Forest, Uganda. In A. Gautier-Hion, F. Bourlière, J.-P. Gautier, \& J. Kingdon (Eds.), A primate radiation: Evolutionary biology of the African guenons (pp. 364-388). Cambridge: Cambridge University Press.

TANAPA, TAWIRI, WD-MNRT, USFWS, USAID, et al. (2015). Gombe-Mahale Ecosystem Conservation Action Planning v2.0.

Tapper, S., Johnson, C., Lenoël, A., Vining, A., Stewart, F., \& Piel, A. (2019). Riverine red-tails: Preliminary data on forest guenons in a savanna woodland habitat in the Issa Valley, Ugalla, western Tanzania. In K. Nowak, A. Barnett, \& I. Matsuda (Eds.), Primates in flooded habitats: Ecology and conservation (pp. 270-275). Cambridge: Cambridge University Press.

Teelen, S. (2007). Primate abundance along five transect lines at Ngogo, Kibale National Park, Uganda. American Journal of Primatology, 69(9), 1030-1044.

Thomas, L., Buckland, S. T., Rexstad, E. A., Laake, J. L., Strindberg, S., et al (2010). Distance software: Design and analysis of distance sampling surveys for estimating population size. Journal of Applied Ecology, 47(1), 5-14.

Thomas, S. C. (1991). Population densities and patterns of habitat use among anthropoid primates of the Ituri Forest, Zaire. Biotropica, 23(1), 68-83.

Tranquilli, S., Abedi-Lartey, M., Abernethy, K., Amsini, F., Asamoah, A., et al (2014). Protected areas in tropical Africa: Assessing threats and conservation activities. PLOS ONE, 9(12), e114154.

Uehara, S. (2003). Population densities of diurnal mammals sympatric with the chimpanzees of the Mahale Mountains, Tanzania: Comparison between the census data of 1996 and 2000. African Study Monographs, 24(3), 169-179.

Watts, D. P., \& Mitani, J. C. (2002). Hunting behavior of chimpanzees at Ngogo, Kibale National Park, Uganda. International Journal of Primatology, 23(1), 1-28.

Wich, S., \& Marshall, A. J. (2016). An introduction to primate conservation. In S. Wich \& A. J. Marshall (Eds.), An introduction to primate conservation (pp. 1-12). Oxford: Oxford University Press.

Wily, L. A. (2001). Forest management and democracy in East and Southern Africa: Lessons from Tanzania. Gatekeeper Series 95. London: International Institute for Environment and Development. 
Wily, L. A., \& Dewees, P. A. (2001). From users to custodians: Changing relations between people and the state in forest management in Tanzania. Policy Research Working Paper, WPS 2569. Environment and Social Development Unit, The World Bank.

Wrangham, R. W., \& van Zinnicq Bergmann Riss, E. (1990). Rates of predation on mammals by Gombe chimpanzees, 1972-1975. Primates, 31(2), 157-170.

Zinner, D., Keller, C., Nyahongo, J. W., Butynski, T. M., de Jong, Y. A., et al (2015). Distribution of mitochondrial clades and morphotypes of baboons Papio spp. (Primates: Cercopithecidae) in Eastern Africa. Journal of East African Natural History, 104(1-2), 143-168.

\section{Affiliations}

\section{Edward McLester ${ }^{1} \cdot$ Lilian Pintea $^{2}$ - Fiona A. Stewart ${ }^{1,3} \cdot$ Alex K. Piel $^{1,3}$}

1 School of Natural Sciences and Psychology, Liverpool John Moores University, Liverpool, UK

2 The Jane Goodall Institute, Arlington, VA, USA

3 Greater Mahale Ecosystem Research and Conservation Project, Box 60118, Dar es Salaam, Tanzania 